Artikel Review

\title{
Hubungan Psikososial dan Status Gizi pada Remaja Wanita dengan Anoreksia Nervosa
}

\author{
Nandya Fatimah Azzahara, Devieka Rhama Dhanny* \\ Program Studi Gizi, Fakultas Ilmu-Ilmu Kesehatan, Universitas Muhammadiyah Prof. Dr. Hamka, Indonesia \\ *Corresponding author: devieka_rd@uhamka.ac.id
}

\begin{abstract}
Background: The occurrence of anorexia nervosa could be at risk with serious nutritional problems in the future. Psychosocial factors are one of the causes of anorexia nervosa. The teenage phase causes psychological changes that lead to anorexia nervosa. The aim of this study is to know the relationship between psychosocial and nutritional status in anorexia nervosa. Literature study from year 2010 to 2020. Data obtained from databases include PubMed, Proquest, American Journal of Clinical Nutrition (AJCN), and Wiley Online with the keywords anorexia nervosa, adolescent females, psychosocial, nutrition. Results: This literature study found 6 articles that match the inclusion and exclusion criteria. From the review of the article, it is known that there are characteristics of anorexia nervosa adolescents, the causes of anorexia nervosa, psychosocial relationships, and nutritional status with anorexia nervosa. Conclusion: Psychosocial factors influence the incidence of anorexia nervosa which can cause serious health problems.
\end{abstract}

Keywords: anorexia nervosa, nutrition, psychosocial, adolescent females

\begin{abstract}
ABSTRAK
Latar Belakang: Kejadian anoreksia nervosa dapat berisiko dengan masalah gizi yang serius di masa depan. Faktor psikososial salah satu penyebab terjadinya anoreksia nervosa. Fase remaja menimbulkan perubahan psikis yang memicu terjadinya anoreksia nervosa. Tujuan dari penelitian adalah untuk mengetahui hubungan antara psikososial dan status gizi pada anoreksia nervosa. Studi literatur tahun 2010 sampai 2020 dan berbahasa Inggris. Data didapat dari database meliputi PubMed, Proquest, American Journal Clinical Nutrition (AJCN), dan Wiley Online dengan kata kunci anoreksia nervosa, adolescent females, psychosocial, nutrition. Hasil: Studi literatur ini didapatkan 6 artikel yang sesuai dengan kriteria inklusi dan ekslusi. Dari tinjauan artikel diketahui ada karakteristik remaja anoreksia nervosa, penyebab anoreksia nervosa, hubungan psikososial dan status gizi dengan anoreksia nervosa. Kesimpulan: Faktor psikososial mempengaruhi kejadian anoreksia nervosa yang dapat menimbulkan masalah kesehatan yang serius.
\end{abstract}

Kata kunci: anoreksia nervosa, nutrisi, psikososial, remaja wanita 


\section{PENDAHULUAN}

Kegemukan merupakan kejadian yang menggambarkan seseorang mengalami penimbunan massa lemak akibat asupan gizi yang berlebih. Hal tersebut tentu dapat memicu penyakit degeneratif dan menyebabkan seseorang kurang percaya diri. Salah satu cara untuk mengatasi kegemukan yang kerap menjadi sorotan di kalangan wanita khususnya remaja yaitu anoreksia nervosa (1).

Anoreksia nervosa seringkali dilakukan oleh beberapa orang yang sangat takut mengalami kegemukan dan meyakini bahwa cara ini mampu menurunkan berat badan secara cepat. Menurut Diagnostic and Statistical Manual for Mental Disorders Fourth Edition (DSM-IV-TR), anoreksia nervosa digolongkan menjadi salah satu gangguan makan yang disebabkan oleh faktor psikologis dimana adanya keinginan untuk memiliki bentuk tubuh langsing namun sangat terobsesi dan tidak pernah puas dengan bentuk tubuhnya (1). Jenis gangguan ini memiliki ciri-ciri berat badan kurang dari $85 \%$ dibandingkan dengan orang-orang normal akibat dari adanya pembatasan asupan makan yang berlebihan (2). Selain itu, orang yang mengalami anoreksia nervosa memiliki pandangan salah terhadap tubuh dimana mereka meyakini bahwa tubuh yang ideal didapatkan jika berat badan sangat jauh lebih rendah dari normal.

Remaja merupakan masa yang menandakan awal mula masa pubertas terjadi. Ada tiga tahapan dalam mengklasifikasikan remaja, yaitu remaja awal berlangsung ketika umur 10 hingga 13 tahun, dilanjutkan dengan tahap remaja pertengahan ketika umur 14 hingga 15 tahun dan remaja akhir ketika umur 16 hingga 19 tahun. Fase remaja ditandai dengan adanya perubahan fisik, emosi dan psikis atau disebut masa pubertas karena periode ini berlangsung masa pematangan organ reproduksi (3). Masa pubertas itulah yang menyebabkan remaja lebih mementingkan perubahan fisik daripada perilakunya. Kasus ini juga dialami sebagian besar oleh wanita dengan prevalensi yang berkisar antara 4 hingga $6 \%$ untuk wanita sedangkan $1 \%$ pada pria (4). Di Indonesia terdapat $38 \%$ orang yang memiliki gangguan pola makan atau yang mengalami kehilangan nafsu makan dan kebanyakan dari mereka adalah wanita, sedangkan terdapat $8,7 \%$ remaja usia $13-15$ tahun dan 8,1\% remaja usia 16-18 tahun dengan kondisi kurus dan sangat kurus (5). Hal tersebut dapat disebabkan adanya anoreksia nervosa, namun belum diketahui secara jelas mengenai prevalensi anoreksia nervosa yang menyebabkan terjadinya remaja kurus dan sangat kurus di Indonesia (1).

Anoreksia nervosa dapat disebabkan oleh 3 faktor, yaitu faktor biologis, faktor psikologis dan faktor sosial (6). Beberapa penelitian menemukan bahwa adanya gangguan di mekanisme kerja otak dimana untuk mengontrol kesenangan dan selera makan sehingga seseorang mudah depresi dan juga mempengaruhi tingkat nafsu makan (7). Dari segi psikologis, seseorang dengan anoreksia nervosa cenderung kurang menghargai dirinya sendiri. Hal ini bisa terjadi dari pengaruh lingkungan di sekitarnya sehingga orang dengan anoreksia nervosa terus menerus mengupayakan segala hal demi terlihat menarik bagi orang lain. Hal ini juga mendasari hubungan pengaruh bullying terhadap anoreksia nervosa (8). Faktor sosial bisa berasal dari pengaruh keluarga. Adanya konflik keluarga, penghinaan terhadap anggota keluarga, keluarga yang kurang memberikan perhatian dan 
dukungan menimbulkan stress atau kesal dapat memicu anoreksia nervosa.

Dari keadaan psikososial yang kurang baik seringkali memicu dengan melakukan hal-hal yang cukup membahayakan diri, salah satunya yaitu membatasi asupan makanan yang sangat berlebihan. Akibatnya, hal ini memicu berbagai dampak buruk yang bersifat jangka pendek maupun jangka panjang di kemudian hari. Hal tersebut dapat berupa gangguan pada jaringan endokrin yang menyebabkan terjadinya amenorea, yaitu kurangnya tiga periode menstruasi berturut-turut pada menstruasi pertama yang merupakan tanda awal seseorang memasuki fase remaja (9). Tak hanya itu, anoreksia nervosa juga menyebabkan anemia gizi, menurunnya massa otot, depresi, dan menurunnya densitas tulang dan meningkatnya kelainan mineral tulang pada wanita (10). Anoreksia nervosa menyebabkan hipotalamus tidak dapat lagi memproduksi hormon sehingga terjadinya hambatan dalam pematangan folikel dan ovulasi di ovarium (11). Wanita dengan anoreksia nervosa juga dapat berisiko mengalami kehamilan yang tidak normal sehingga dapat melahirkan bayi prematur (12). Pada penelitian sebelumnya menemukan bahwa wanita dengan anoreksia nervosa dapat berisiko sebanyak 1,77 kali terhadap kejadian bayi lahir prematur (13).

Namun di era sekarang dimana setiap individu kurang memperhatikan keadaan sekitar yang menyebabkan interaksi antara sesama individu kurang akrab. Hal tersebut dapat mempengaruhi psikis seseorang dan memicu terjadinya kejadian anoreksia nervosa. Apabila anoreksia nervosa tidak segera dicegah ataupun dilakukan intervensinya, maka dampak buruk yang ditimbulkan akan dialami dalam jangka panjang. Wanita dengan anoreksia nervosa sangat berisiko memiliki anak dengan masalah gizi seperti stunting, gizi buruk, dan lain-lain di masa depan (14). Berdasarkan data-data yang telah diperoleh, peneliti tertarik untuk melaksanakan jurnal review terkait hubungan psikis dan status gizi terhadap remaja wanita dengan anoreksia nervosa.

Artikel diperoleh dari database elektronik yakni PubMed, Proquest, American Journal Clinical Nutrition (AJCN), Wiley Online, dan bibliografi. Kata kunci yang gunakan dalam menelusuri artikel yaitu "anoreksia nervosa", kemudian ditambahkan dengan kata "adolescent females" untuk menemukan artikel terkait remaja wanita. Setelah itu menambahkan kata kunci "psychosocial", dan terakhir yaitu "nutrition" dan "nutritional status".

Artikel yang dipilih harus memuat kriteria inklusi yaitu lengkap dengan judul dan isi yang sesuai dengan tujuan, responden yang berjenis kelamin wanita dengan usia remaja, serta artikel yang dipublikasikan dari 2010 hingga 2020. Sedangkan kriteria eksklusi yaitu struktur tidak lengkap dan tidak sesuai dengan kata kunci.

Dari total 69 artikel (63 dihilangkan), terdapat 6 artikel yang dipilih. Kemudian artikel dianalisis dengan cermat secara keseluruhan. Walaupun teknik pada review ini dilakukan tidak secara statistik, namun hasil dan kesimpulan yang diperoleh dapat menjadi sumber referensi terpercaya terkait hubungan psikis dan dampak terhadap gizi pada remaja wanita dengan anoreksia nervosa. 


\section{DIAGRAM ALIR PENCAHARIAN JURNAL-JURNAL}

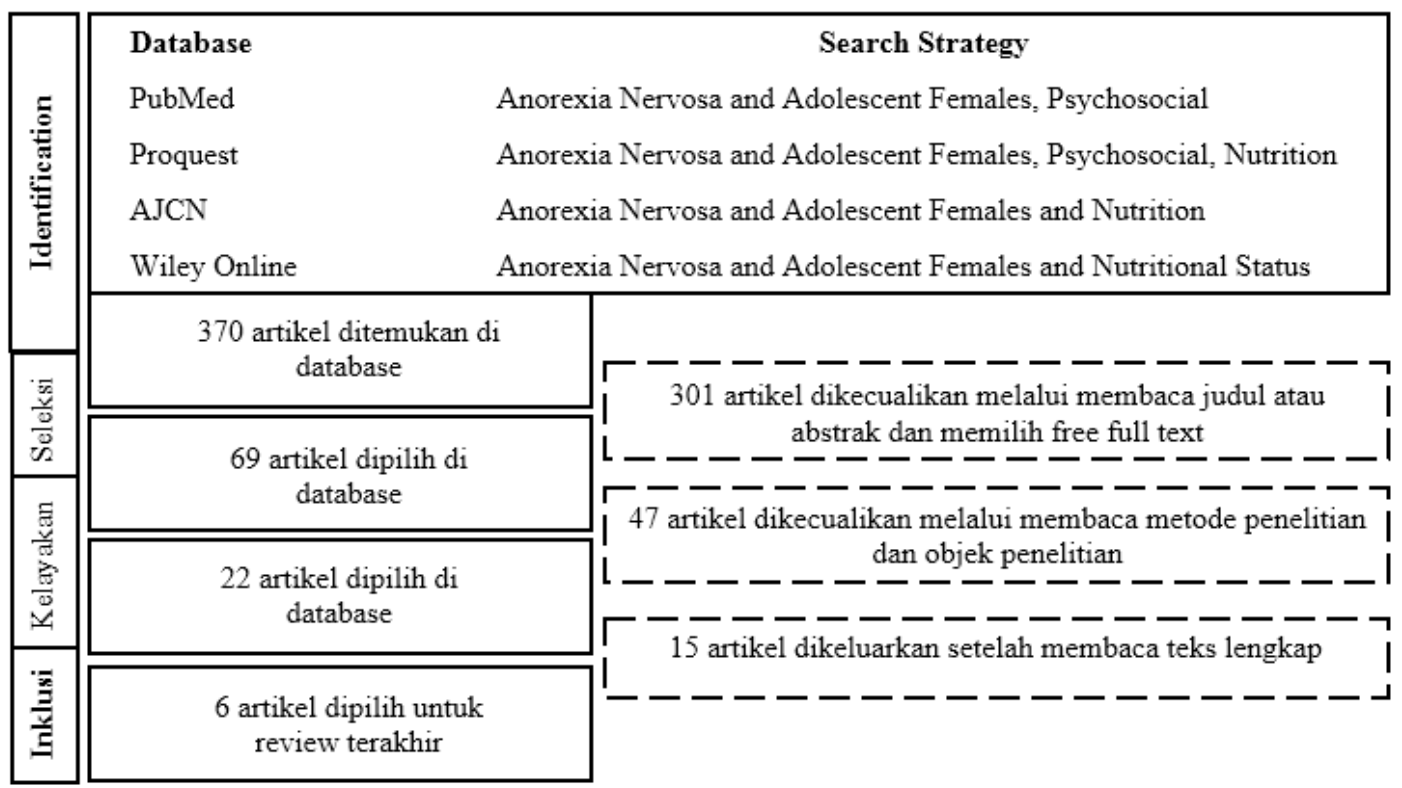

\section{TINJAUAN LITERATUR}

Hasil kajian terkait hubungan psikososial dan status gizi terhadap anoreksia nervosa, terdapat 6 artikel yang diperoleh di Tabel 1 .

Pada Tabel 1, dari 6 artikel yang telah dianalisis, terdapat 3 artikel yang terkait dengan asupan zat gizi dan 3 artikel yang memuat faktor psikososial pada anoreksia nervosa. Pembatasan asupan makan yang sangat berlebihan menyebabkan asupan zat gizi mengalami defisit tingkat berat. Hal ini didasari oleh salah satu penyebab yaitu faktor psikososial. Faktor tersebut berasal dari keadaan lingkungan sekitar yang tidak mendukung sehingga dapat memperburuk keadaan psikis seseorang. Dari tinjauan artikel diketahui ada pengaruh psikososial, penyebab anoreksia nervosa, dampak anoreksia nervosa terhadap gizi seseorang dan hubungan psikososial dengan anoreksia nervosa.

Faktor psikis mempengaruhi pola makan. Hal tersebut dibuktikan dalam sebuah penelitian yang menunjukkan adanya korelasi antara kesulitan dalam fleksibilitas kognitif dan kesulitan dalam fungsi sosiokognitif yang mempengaruhi psikis seseorang terkait dengan anoreksia nervosa (15). Apabila keadaan psikis pada seseorang terganggu, maka akan berdampak pada pola makan yang tidak teratur sehingga anoreksia nervosa dapat terjadi dengan keadaan psikis yang buruk. Dari tinjauan Naor-Ziv R, dkk (2016) gangguan psikis secara signifikan terkait dengan kejadian anoreksia nervosa karena dapat menghambat perkembangan otak. Akibatnya, fungsifungsi otak menjadi terganggu sehingga fleksibilitas kognitif dan perilaku menjadi rendah (16). Maka dari itu, timbul rasa keinginan untuk menjadi perfeksionis secara berlebihan yang merupakan ciri-ciri dari anoreksia nervosa pada seseorang. anoreksia nervosa umumnya mempengaruhi sebagian besar pada remaja wanita karena mereka akan terlihat cantik apabila terlihat kurus (17). Selain itu, adanya stigma sosial yang seringkali tidak mendukung bagaimana penampilan seseorang. Hal ini tentu dapat berpengaruh terhadap keadaan psikis seseorang. Sehingga anoreksia nervosa merupakan salah satu gangguan pola makan yang sangat berhubungan erat dengan keadaan psikis yang kurang baik. 
Tabel 1. Daftar Literature Review Jurnal

\begin{tabular}{|c|c|c|c|c|c|c|c|}
\hline No. & $\begin{array}{c}\text { Nama Author dan } \\
\text { Tahun }\end{array}$ & Nama Jurnal & Judul Penelitian & Tujuan Penelitian & Desain atau Metode & Sampel & Hasil \\
\hline 1. & $\begin{array}{l}\text { Nathalie Godart, Sylvie } \\
\text { Berthoz, Florence Curt, } \\
\text { Fabienne Perdereau, Zoe' } \\
\text { Rein, Jenny } \\
\text { Wallier, dkk (2012) }\end{array}$ & PloS ONE & $\begin{array}{l}\text { Randomized Controlled } \\
\text { Trial of Adjunctive } \\
\text { Family } \\
\text { Therapy and Treatment } \\
\text { as Usual Following } \\
\text { Inpatient } \\
\text { Treatment for } \\
\text { Anoreksia nervosa } \\
\text { Adolescents }\end{array}$ & $\begin{array}{l}\text { Untuk membandingkan } \\
\text { dua program pengobatan } \\
\text { rawat jalan untuk remaja } \\
\text { dengan AN berat: } \\
\text { Pengobatan seperti } \\
\text { Biasa (TAU) versus } \\
\text { pengobatan ini ditambah } \\
\text { terapi keluarga (TAU + } \\
\text { FT). }\end{array}$ & $\begin{array}{c}\text { randomized-controlled } \\
\text { trial }\end{array}$ & $\begin{array}{l}60 \text { remaja } \\
\text { wanita } \\
\text { dengan AN } \\
\text { usia } 13-19 \\
\text { tahun }\end{array}$ & $\begin{array}{l}\text { Pengobatan biasa } \\
\text { ditambah terapi } \\
\text { keluarga } \\
\text { memberikan hasil } \\
\text { yang signifikan } \\
\text { dalam hal } \\
\text { pencapaian berat } \\
\text { badan yang sehat } \\
\text { dan status } \\
\text { menstruasi. }\end{array}$ \\
\hline 2. & $\begin{array}{l}\text { Verena Haas, Dorothea } \\
\text { Kent, Michael R Kohn, } \\
\text { Sloane Madden, Simon } \\
\text { Clarke, dkk } \\
\text { (2018) }\end{array}$ & $\begin{array}{l}\text { American } \\
\text { Society for } \\
\text { Nutrition }\end{array}$ & $\begin{array}{l}\text { Incomplete total body } \\
\text { protein recovery in } \\
\text { adolescent patients } \\
\text { with anoreksia nervosa }\end{array}$ & $\begin{array}{l}\text { untuk menganalisis } \\
\text { prediktor status protein } \\
\text { pada remaja dengan AN } \\
\text { dan untuk menyelidiki } \\
\text { apakah penambahan } \\
\text { berat badan akan } \\
\text { mengisi kembali defisit } \\
\text { protein tubuh }\end{array}$ & $\begin{array}{c}\text { Studi observasional } \\
\text { longitudinal }\end{array}$ & $\begin{array}{l}103 \text { remaja } \\
\text { wanita } \\
\text { dengan AN } \\
\text { berusia } 12- \\
19 \text { tahun }\end{array}$ & $\begin{array}{l}\text { Remaja yang pulih } \\
\text { dari AN dapat } \\
\text { mencapai berat } \\
\text { badan yang } \\
\text { normal namun } \\
\text { memerlukan } \\
\text { waktu yang } \\
\text { bertahap untuk } \\
\text { mencapai protein } \\
\text { tubuh yang } \\
\text { adekuat. }\end{array}$ \\
\hline 3. & $\begin{array}{l}\text { Marian Tanofsky-Kraff, } \\
\text { Lauren B Shomaker, } \\
\text { Denise E Wilfley, Jami F } \\
\text { Young, Tracy Sbrocco, } \\
\text { dkk (2014) }\end{array}$ & $\begin{array}{l}\text { American } \\
\text { Society for } \\
\text { Nutrition }\end{array}$ & $\begin{array}{l}\text { Targeted prevention of } \\
\text { excess weight gain and } \\
\text { eating disorders in } \\
\text { high-risk adolescent } \\
\text { girls }\end{array}$ & $\begin{array}{l}\text { Untuk membuktikan } \\
\text { bahwa program } \\
\text { pencegahan psikoterapi } \\
\text { interpersonal lebih } \\
\text { efektif daripada } \\
\text { pendidikan kesehatan } \\
\text { dalam mengatasi pola } \\
\text { makan yang tidak teratur }\end{array}$ & $\begin{array}{l}\text { randomized controlled } \\
\text { trial }\end{array}$ & $\begin{array}{l}113 \\
\text { Remaja } \\
\text { wanita } \\
\text { berusia } 12- \\
17 \text { tahun }\end{array}$ & $\begin{array}{l}\text { Psikoterapi } \\
\text { interpersonal } \\
\text { mampu } \\
\text { mengendalikan } \\
\text { remaja dari pola } \\
\text { makan yang tidak } \\
\text { teratur dan } \\
\text { suasana hati } \\
\text { membaik selama } 1 \\
\text { tahun. }\end{array}$ \\
\hline
\end{tabular}


4. Charumathi Baskaran,

Traci L. Carson, Karen J.

Campoverde Reyes,

Kendra R. Becker,

Meghan J. Slattery, dkk

(2016)

5. C. Alix Timko, Tiffanie J. Goulazian, Kathleen

Kara Fitzpatrick and

Daniel Rodriguez (2018)

6. L. Maïmoun, $\mathrm{S}$.

Guillaume, P. Lefebvre,

P. Philibert, H. Bertet,

M.-C. Picot, L. Gaspari,

F. Paris, M. Seneque, A.-

M. Dupuys, P. Courtet, E.

Thomas, D. Mariano-

Goulart, J. Bringer, E.

Renard, C. Sultan (2015)

$\begin{array}{cll}\text { International } & \text { Macronutrient intake } & \text { Untuk menyelidiki } \\ \text { Journal of } & \text { associated with weight } & \text { secara prospektif } \\ \text { Eating Disorders } & \text { gain in adolescent } & \text { komposisi makronutrien } \\ & \text { girls with anoreksia } & \text { makanan yang terkait } \\ & \text { nervosa } & \begin{array}{l}\text { dengan penambahan } \\ \text { berat badan pada remaja } \\ \end{array} \\ & & \text { perempuan dengan AN }\end{array}$

Pilot and

Feasibility

Studies

Osteoporos Int

$\begin{array}{ll}\text { Cognitive remediation } & \text { untuk mengevaluasi } \\ \text { therapy (CRT) as a } & \text { kelayakan dan } \\ \text { pretreatment } & \text { melakukan uji coba } \\ \text { intervention for } & \text { prosedur untuk CRT } \\ \text { adolescents } & \text { dengan komponen }\end{array}$

with anoreksia nervosa

during medical

hospitalization: a pilot

randomized

controlled trial protocol

Evidence of a link

between resting energy

expenditure and bone

remodelling, glucose

homeostasis and

adipokine variations

in adolescent girls with

anoreksia nervosa

\begin{tabular}{|c|c|c|}
\hline $\begin{array}{c}\text { A prospective } \\
\text { naturalistic study }\end{array}$ & $\begin{array}{l}90 \text { remaja } \\
\text { wanita } \\
\text { berusia } 12- \\
18 \text { tahun ( } 45 \\
\text { orang dengan } \\
\text { AN dan } 45 \\
\text { orang tanpa } \\
\text { AN) }\end{array}$ & $\begin{array}{l}\text { Mengkonsumsi } \\
\text { makanan dengan } \\
\text { porsi yang lebih } \\
\text { besar dari total } \\
\text { kalori } \\
\text { berhubungan } \\
\text { dengan } \\
\text { penambahan berat } \\
\text { badan pada remaja } \\
\text { putri dengan AN }\end{array}$ \\
\hline $\begin{array}{l}\text { uji coba terkontrol } \\
\text { secara acak }\end{array}$ & $\begin{array}{l}60 \text { remaja } \\
\text { wanita } \\
\text { pasien } \\
\text { Rumah Sakit } \\
\text { Anak } \\
\text { Philadelphia } \\
\text { yang berusia } \\
\text { 12-18 tahun } \\
\text { dengan AN }\end{array}$ & $\begin{array}{l}\text { CRT dengan } \\
\text { komponen } \\
\text { keluarga secara } \\
\text { signifikan dapat } \\
\text { mengobati remaja } \\
\text { dengan AN dan } \\
\text { layak diberikan di } \\
\text { rumah sakit untuk } \\
\text { stabilisasi medis. }\end{array}$ \\
\hline Case-control & $\begin{array}{l}100 \text { orang } \\
\text { remaja dan } \\
\text { wanita muda } \\
\text { dengan AN } \\
\text { usia } 14.4 \\
\text { hingga } 23.8 \\
\text { tahun }\end{array}$ & $\begin{array}{l}\text { REEm } \\
\text { (Perhitungan } \\
\text { Energi Basal) } \\
\text { berkorelasi positif } \\
\text { dengan berat } \\
\text { badan, BMI, } \\
\text { massa lemak, } \\
\text { penanda jaringan } \\
\text { lunak bebas lemak } \\
\text { untuk } \\
\text { pembentukan } \\
\text { tulang pada pasien } \\
\text { AN }\end{array}$ \\
\hline
\end{tabular}




\section{Status Gizi}

Status gizi pada penderita anoreksia nervosa yaitu $<15 \mathrm{~kg} / \mathrm{m}^{2}$ (3). Status gizi yang sangat kurang ini merupakan akibat dari pola makan yang tidak teratur dan merupakan ciri khas dari anoreksia nervosa (18). Anoreksia nervosa menyebabkan seseorang membatasi asupan makan sehingga asupan gizi makro maupun mikro tidak dipenuhi secara optimal (19). Remaja dengan anoreksia nervosa mengkonsumsi makanan padat dengan kandungan energi yang rendah namun dalam jumlah yang banyak agar dapat menekan rasa lapar (20). Selain asupan energi, mereka juga sangat membatasi asupan terutama asupan lemak dengan jenis apapun (21). Penderita anoreksia nervosa juga diimbangi dengan olahraga yang berlebihan sehingga menyebabkan protein dalam tubuh sangat rendah (22). Zat gizi yang tidak seimbang menyebabkan organ-organ mengalami kesulitan dalam melakukan fungsinya akibat adanya gangguan metabolisme sehingga hal ini menimbulkan masalah kesehatan yang sangat serius (23).

\section{Hubungan Faktor Psikososial dan Status Gizi pada Anoreksia Nervosa}

Keadaan psikis yang buruk memiliki hubungan yang kuat dengan kejadian anoreksia nervosa. Keadaan psikososial yang kurang baik dapat mempengaruhi seseorang untuk membatasi asupan makanan yang sangat ekstrim. Hal ini menyebabkan seseorang tidak memenuhi asupan zat gizi yang sesuai. Hal ini dapat dibuktikan dengan hasil pengukuran status gizi yang sangat minim. Maka dari itu, anoreksia nervosa memiliki pengaruh terhadap terjadinya status gizi yang sangat rendah (24).

\section{SIMPULAN}

Berdasarkan hasil telaah dari 6 jurnal yang dilakukan, faktor psikososial yang mempengaruhi anoreksia nervosa adalah keadaan psikis seseorang serta keadaan lingkungan sekitar. Selain itu, anoreksia nervosa menyebabkan seseorang membatasi asupan zat gizi yang dapat menimbulkan penurunan status gizi pada remaja wanita. Hal ini merupakan dampak yang serius dan perlu diatasi lebih lanjut untuk menghindari terjadinya berbagai masalah gizi. Sehingga diperlukan adanya peran dari orang-orang terdekat, khususnya peran keluarga yang sangat menentukan keberhasilan dalam pemulihan status gizi pada seseorang dengan anoreksia nervosa.

\section{UCAPAN TERIMA KASIH}

Ucapan terima kasih kepada semua pihak yang telah memberikan banyak bantuan serta dukungan sehingga penulis mampu menyelesaikan artikel review ini.

\section{KONFLIK KEPENTINGAN}

Penulis tidak memiliki konflik kepentingan dan tidak ada afiliasi atau koneksi dengan organisasi apapun yang dapat menimbulkan pertanyaan bias dalam diskusi dan kesimpulan artikel review ini.

\section{REFERENSI}

1. Krisnani H, Santoso MB, Putri D. Gangguan Makan Anoreksia nervosa dan Bulimia Nervosa Pada Remaja. In: Prosiding Penelitian dan Pengabdian kepada Masyarakat [Internet]. 2018. p. 399. Available from:

http://jurnal.unpad.ac.id/prosiding/a rticle/view/18618

2. Doyle PM, Le Grange D, Loeb K, Doyle AC, Crosby RD. Early response to family-based treatment 
for adolescent anoreksia nervosa. Int J Eat Disord. 2010;43(7):659-62.

3. Mustelin L, Silén Y, Raevuori A, Hoek HW, Kaprio J, KeskiRahkonen A. The DSM-5 diagnostic criteria for anoreksia nervosa may change its population prevalence and prognostic value. J Psychiatr Res. 2016;77:85-91.

4. Ward ZJ, Rodriguez P, Wright DR, Austin SB, Long MW. Estimation of Eating Disorders Prevalence by Age and Associations With Mortality in a Simulated Nationally Representative US Cohort. JAMA Netw open. 2019;2(10):e1912925.

5. Kementerian Kesehatan RI. Gizi saat Remaja Tentukan Kualitas Keturunan. 2020 p. 24-5.

6. McAdams CJ, Krawczyk DC. Impaired neural processing of social attribution in anoreksia nervosa. Psychiatry Res - Neuroimaging. 2011;194(1):54-63.

7. Berridge KC, Ho CY, Richard JM, Difeliceantonio AG. The tempted brain eats: Pleasure and desire circuits in obesity and eating disorders. Brain Res. 2010;1350:4364.

8. Lee KS, Vaillancourt T. A FourYear Prospective Study of Bullying, Anxiety, and Disordered Eating Behavior Across Early Adolescence. Child Psychiatry Hum Dev. 2019;50(5):815-25.

9. Sitoayu L, Pertiwi DA, Mulyani EY. Kecukupan zat gizi makro, status gizi, stres, dan siklus menstruasi pada remaja. J Gizi Klin Indones. 2017;13(3):121.

10. Meczekalski B, Podfigurna-Stopa A, Katulski K. Long-term consequences of anoreksia nervosa. Maturitas.
2013;75(3):215-20.

11. Frank GKW, Deguzman MC, Shott ME, Laudenslager ML, Rossi B, Pryor T. Association of Brain Reward Learning Response with Harm Avoidance, Weight Gain, and Hypothalamic Effective Connectivity in Adolescent Anoreksia nervosa. JAMA Psychiatry. 2018;75(10):107180.

12. Linna MS, Raevuori A, Haukka J, Suvisaari JM, Suokas JT, Gissler M. Pregnancy, obstetric, and perinatal health outcomes in eating disorders. Am J Obstet Gynecol. 2014;211(4):392.e1-392.e8.

13. Micali N, Stemann Larsen $P$, Strandberg-Larsen K, Nybo Andersen AM. Size at birth and preterm birth in women with lifetime eating disorders: a prospective population-based study. BJOG An Int J Obstet Gynaecol. 2016;123(8):1301-10.

14. Cederholm T, Jensen GL, Correia MITD, Gonzalez MC, Fukushima R, Higashiguchi T, et al. GLIM criteria for the diagnosis of malnutrition - A consensus report from the global clinical nutrition community. Clin Nutr. 2019;38(1):1-9.

15. Naor-Ziv R, Glicksohn J. Investigating Cognitive Deficits as Risk Factors for Developing Eating Disorders During Adolescence. Dev Neuropsychol. 2016;41(1-2):10724.

16. Timko CA, Goulazian TJ, Fitzpatrick KK, Rodriguez D. Cognitive remediation therapy (CRT) as a pretreatment intervention for adolescents with anoreksia nervosa during medical hospitalization: A pilot randomized controlled trial protocol. Pilot Feasibility Stud. 2018;4(1):1-16. 
17. Godart N, Berthoz S, Curt F, Perdereau F, Rein Z, Wallier J, et al. A randomized controlled trial of adjunctive family therapy and treatment as usual following inpatient treatment for anoreksia nervosa adolescents. PLoS One. 2012;7(1).

18. Tanofsky-Kraff M, Shomaker LB, Wilfley DE, Young JF, Sbrocco T, Stephens M, et al. Targeted prevention of excess weight gain and eating disorders in high-risk adolescent girls: A randomized controlled trial. Am J Clin Nutr. 2014;100(4):1010-8.

19. Baskaran C, Carson TL, Campoverde Reyes KJ, Becker KR, Slattery MJ, Tulsiani S, et al. Macronutrient intake associated with weight gain in adolescent girls with anoreksia nervosa. Int J Eat Disord. 2017;50(9):1050-7.

20. Jáuregui Lobera I, Bolaños Ríos P. Choice of diet in patients with anoreksia nervosa. Nutr Hosp. 2011;24(6):682-7.

21. Maïmoun L, Guillaume S, Lefebvre P, Philibert P, Bertet H, Picot MC, et al. Evidence of a link between resting energy expenditure and bone remodelling, glucose homeostasis and adipokine variations in adolescent girls with anoreksia nervosa. Osteoporos Int. 2016;27(1):135-46.

22. Haas V, Kent D, Kohn MR, Madden S, Clarke S, Briody J, et al. Incomplete total body protein recovery in adolescent patients with anoreksia nervosa. Am J Clin Nutr. 2018;107(3):303-12.

23. Saunders J, Smith T. Malnutrition: Causes and consequences. Clin Med
J R Coll Physicians London. 2010;10(6):624-7.

24. Anggraeni SD. Hubungan antara Body Image dengan Frekuensi Makan, Jenis Makanan dan Status Gizi Remaja Putri. Progr Stud Ilmu Gizi , Fak Ilmu Kesehatan, Univ Muhammadiyah Surakarta. 2015;114. 